\title{
PERAN PEMERINTAH DESA UNTUK MENINGKATKAN PARTISIPASI MASYARAKAT DALAM MUSYAWARAH PERENCANAAN PEMBANGUNAN DI DESA KULO
}

\author{
Rindy Arisandi \\ Prodi Ilmu Admnistrasi Publik Fakultas Ilmu Sosial dan Ilmu Politik \\ Universitas Muhammadiyah Sidenreng Rappang \\ rindyarisandi18@gmail.com
}

\begin{abstract}
ABSTRAK
Artikel ini bertujuan untuk mengetahui peranan pemerintah desa untuk meningkatkan partisipasi masyarakat dalam Musyawarah Perencanaan Pembangunan di Desa Kulo Kecamatan Kulo Kabupaten Sidenreng Rappang. Hambatan dan keterlambatan pembangunan desa pada umumnya disebabkan oleh tidak tersedia sumber daya manusia (SDM) yang potensial, mentalitas aparat pemerintah desa dalam melaksanakan tugas pokok dan fungsi sebagai kewenangan dan kewajiban pemerintah desa, kekurangan fasilitas sarana dan prasarana pelayanan, desa terpencil dan kekurangan dana. Untuk itu, maka proses perencanaan memerlukan keterlibatan masyarakat, diantaranya dengan melakukan musyawarah perencanaan pembangunan (musrenbang). Penyelenggaraan musrenbang meliputi tahap persiapan, diskusi dan perumusan prioritas program/kegiatan, partisipasi masyarakat disuatu desa sangatlah penting .

Masyarakat desa diberikan kekuasaan oleh negara melalui UU nomor 6 tahun 2014 tentang desa sebagai wewenang mengatur dan mengurus urusan pemerintah untuk memenuhi kepentingan hidup dan kehidupan masyarakat desa atas prakarsa pembangunan desa yang dipikir dan rancang sendiri oleh lembaga-lembaga kemasyarakatan desa dan lembaga pemerintahan desa melalui musyawarah dan mufakat. Hasil artikel ini menunjukkan bahwa peran pemerintah desa dalam Musyawarah Perencanaan Pembangunan di Desa Kulo Kecamatan Kulo Kabupaten Sidenreng Rappang dengan persentase $76 \%$, partisipasi masyarakat dalam Musyawarah Perencanaan Pembangunan berada pada kategori sangat baik dengan persentase $81 \%$, dan faktor yang mempengaruhi peran pemerintah desa dan partisipasi masyarakat dalam Musyawarah Perencanaan Pembangunan berada pada kategori baik dengan persentase 64\%, dan persentase secara keseluruhan yaitu $76 \%$
\end{abstract}

Kata kunci: Pemerintah desa, partisipasi masyarakat, dan musyawarah perencanaan pembangunan

\section{Pendahuluan}

Pada Undang-Undang No 6/2014 tentang Desa, diuraikan bahwa Pemerintahan Desa bersama masyarakat desa melaksanakan sebuah pendekatan dalam ,membangun desa ${ }^{\text {ee }}$ dan ,desa membangun "e melalui semangat kegotong royongan serta selalu memanfaatkan kearifan lokal yang ada dan sumber daya alam desa untuk tercapainya peningkatan kesejahteraan masyarakat dan kualitas hidup manusia di desa. Disamping itu pula, masyarakat desa yang semakin kritis dan kompleks permasalahannya membutuhkan kegiatan pelayanan yang semakin baik, terarah, terpadu dan yang paling penting adalah berusaha memberdayakan masyarakat dengan segala potensi dan permasalahan yang dihadapi oleh mereka (Mustanir \& Yasin, 2018a)

Dalam perencanaan pembangunan pemerintah desa perlu melibatkan segenap kemampuan dan kemauan yang dimiliki oleh masyarakat dalam melaksanakan pembangunan (partisipatif). Oleh karena itu pemerintah dalam menjalankan proses-proses pemerintahan dalam membangun masyarakat harus menekankan perlunya partisipasi masyarakat dengan beragam kepentingan ataupun latar belakang yang berbeda. Untuk mencapai keberhasilan pembangunan tersebut maka 
banyak aspek yang harus diperhatikan, diantaranya adalah keterlibatan masyarakat dalam pembangunan. (Latif et al., 2019)

Tanpa melibatkan masyarakat dalam proses pembangunan maka pembangunan tidak akan bisa dan tidak menemui sasaran yang dicapai karena kebijakan yang dikeluarkan pemimpin sangat jauh dari aspirasi, kepentingan, dan kebutuhan rakyat. Selain itu, hilangnya partisipasi mengakibatkan memudarnya kontrol rakyat dan akibatnya banyak terjadi pengingkaran amanat rakyat yang berakhir pada proses penyalahgunaan kekuasaan. Partisipasi masyarakat dalam pembangunan bukan hanya dilihat sebagai proses tetapi juga merupakan hasil akhir, yang mana partisipasi masyarakat adalah salah satu indikator yang mempengaruhi hasil pembangunan desa. (Latif et al., 2019)

Aksi kolektif tersebut kemudian mendorong masyarakat lebih siap untuk terlibat dalam proses partisipasi. Pen- dekatan top-down dan partisipatif sesuai amanat UU No. 25 tahun 2004 terwujud dalam sebuah bentuk rangkaian musren- bang yang dilakukan secara berjenjang dari mulai tingkat desa, kecamatan dan kabupaten. Rangkaian forum musrenbang ini menjadi bagian dalam proses penyusunan sistem perencanaan dan anggaran untuk pelaksanaan kegiatan pembangunan se- tiap tahunnya. Melalui musrenbang, masyarakat berpeluang menyampaikan aspirasi mereka dan berpartisipasi dalam menghasilkan dokumen perencanaan pembangunan yang sesuai dengan kebu- tuhan masyarakat(Yunas, 2017)

Berdasarkan hasil observasi di Desa Kulo Kecamatan Kulo Kabupaten Sidenreng Rappang pada tanggal 09 April 2018, artikel ini menemukan masalah yaitu kurang aktifnya masyarakat dalam proses musrenbang sehingga daftar prioritas rencana pembangunan desa yang seharusnya diusulkan dan diajukan langsung oleh masyarakat(Samad et al., 2019)

\section{Pembahasan}

\section{Pemerintah Desa}

Penyelenggaraan Pemerintahan Desa berdasarakan Undang-Undang Nomor 32 tahun 2004 pengaturannya berdasarkan pemikiran keanekaragaman, partisipasi, otonomi asli, demokratisasi dan pemberdayaan masyarakat. Oleh karena itu penyelenggraan pemerintahan desa merupakan subsistem penye- lenggaraan pemerintahan, sehingga desa mempunyai kewenangan untuk mengatur dan mengurus kepentingan masyarakat. (Desa et al., n.d.)

Widjaja (2003: 3) mengemukakan bahwa "desa adalah sebagai kesatuan masyarakat hukum yang mempunyai susunan asli berdasarkan hak asal usul yang bersifat istimewa. Landasan pemikiran dalam mengenai Pemerintahan Desa adalah keanekaragaman, partisipasi, otonomi asli, demokratisasi dan pemberdayaan masyarakat".(Mustanir, Muhammadiyah, Rappang, \& Irwan, 2019)

Menurut Undang-Undang Nomor 32 Tahun 2004 tentang Pemerintahan Daerah, Desa atau yang disebut dengan nama lain, selanjutnya disebut desa, adalah kesatuan masyarakat hukum yang memiliki batas-batas wilayah yang berwenang untuk mengatur dan mengurus kepentingan masyarakat setempat, berdasarkan asal- usul dan adat-istiadat setempat yang diakui dan dihormati dalam sistem Pemerintahan Negara Kesatuan Republik Indonesia.(Mustanir \& Yasin, 2018a)

Pemerintahan Desa adalah penyelenggaraan urusan pemerintahan oleh pemerintah desa dan Badan Permusyawaratan Desa dalam mengatur dan mengurus kepentingan masyarakat setempat berdasarkan asal-usul dan adat istiadat setempat yang diakui dan dihormati dalam sistem Pemerintahan Negara Kesatuan Republik Indonesia (Mustanir et al., 2018)

Peranan Pemerintah desa dalam perencanaan pembangunan menjadi permasalahan yang belum terpecahkan dari masa ke masa dalam sistem penyelenggaraan pemerintah desa di masa orde lama, orde baru dan masa reformasi. Secara umum diketahui sesuai isu yang berkembang selama ini, bahwa hambatan dan keterlambatan pembangunan desa pada umumnya disebabkan oleh tidak tersedia sumber daya manusia (SDM) yang potensial, mentalitas aparat pemerintah desa dalam melaksanakan tugas pokok dan fungsi sebagai kewenangan dan kewajiban pemerintah desa, kekurangan fasilitas sarana dan prasarana pelayanan, desa terpencil dan kekurangan dana.(Kunci et al., 2019) 


\section{Partisipasi Masyarakat}

Partisipasi adalah keikutsertaan seseorang atau sekelompok anggotamasyarakat dalam suatu kegiatan (Mardikanto \& Poerwoko, 2015). Sedangkan Verhangen dalam (Mardikanto \& Poerwoko, 2015) (Irwan et al. 2019) menyatakan bahwa partisipasi merupakan suatu bentuk khusus dari interaksi dan komunikasi yang berkaitan dengan pembangian kewenangan, tanggung jawab, dan manfaat. (Mustanir et al., 2020)

Pengertian partisipasi masyarakat [8], [10], mengemukakan tentang lingkup partisipasi dengan bertolak pada urutan proses perencanaan pembangunan, maka secara rinci jenis partisipasi masyarakat dalam pembangunan sebagai berikut: 1) Partisipasi dalam pengambilan keputusan, 2) Partisipasi dalam pelaksanaan kegiatan, 3) Partisipasi dalam pemantauan dan evaluasi pembangunan, 4) Partisipasi dalam pemanfaatan hasil-hasil pembangunan Dalam Undang-Undang No. 25 Tahun 2004 [16] Sistem Perencanaan Pembangunan Nasional mengartikan "partisipasi masyarakat adalah keikutsertaan masyarakat untuk mengakomodasikan kepentingan mereka dalam proses penyusunan rencana pembangunan"(Mustanir, 2019)

Totok Mardikanto dan Poerwoko Soebiato dalam Ahmad Mustanir (2017: 316-317). Mengemukakan tentang lingkup partisipasi dengan bertolak pada urutan proses perencanaan pembangunan, maka secara rinci jenis partisipasi dalam pembangunan sebagai berikut : 1) Partisipasi dalam pengambilan keputusan, 2) Partisipasi dalam pelaksanaan kegiatan, 3) Partisipasi dalam pemantauan dan evaluasi pembangunan, 4) Partisipasi dalam pemanfaatan hasil-hasil pembangunan. (Mustanir, 2019)

Partisipasi masyarakat merupakan bentuk keikutsertaan masyarakat dalam proses pengidentifikasian masalah dan potensi yang ada di masyarakat, pemilihan dan pengambilan keputusan tentang alternatif alternatif solusi untuk menangani masalah, pelaksanaan upaya mengatasi masalah dan keterlibatan masyarakat dalam proses mengevaluasi perubahan yang terjadi. Partisipasi masyarakat mempunyai peranan penting dalam keberhasilan perencanaan pembangunan. Oleh karena itu, dalam diri masyarakat harus tumbuh suatu kesadaran akan keberadaannya sehingga timbul hasrat untuk turut serta bersama pemerintah dalam membangun negara. (Andi Uceng, 2019)

Partisipasi masyarakat dilaksanakan berdasarkan atas asas: a) Kebebasan berpendapat baik secara lisan maupun tulisan; b) Rasionalitas, efisiensiesi, tepat guna, dan tepat harus sasaran; c) Sesuai dengan norma, prosedur, dan juga etika sosial yang tetap berlaku; dan d) Tanggap. serta terbuka, dan penuh kesungguhan. Peran partisipasi masyarakat dalam proses perumusan kebijakan public juga meliputi Perumusan visi dan misi, rencana strategis, dan program - program lainya seperti pembangunan desa; Penyusunan rencana serta tahapan pembanguan tahunan desa; Penyusunan anggaran pendapatan dan anggaran belanja desa.(Wahyu et al., 2016)

Indikator Partisipasi Masyarakat menurut Mubyarto adalah:

a) Terlibat memikul tanggung jawab pelaksanaan pembangunan

b) Musyawarah perencanaan pembangunan

c) Pelaksana hasil perencanaan pembangunan

d) Kesediaan membayar iuran sebagai dana swadaya

e) Kesediaan masyarakat dalam menyumbang material seperti pasir, batu bata, semen.(Mustanir \& Darmiah, 2016)

Manfaat yang diperoleh dari adanya partisipasi masyarakat, sebagaimana pendapat ahli menurut Westra dalam (Zainuddin, 2017) manfaat partisipasi, antara lain: (a) Lebih dimungkinkan diperolehnya keputusan yang benar; (b) dapat dipergunakannya kemampuan berfikir yang kreatif dari masyarakat; (c) dapat mengembalikan nilai-nilai martabat manusia (human dignity), dorongan (motivasi) serta membangun kepentingan bersama; (d) lebih mendorong orang untuk bertanggung 
jawab; (e) memperbaiki semangat bekerja sama serta menimbulkan kesatuan kerja; (f) lebih memungkinkan mengikuti perubahan-perubahan (Uceng et al. 2019). (Mustanir et al., 2020)

\section{Musyawarah Perencanaan Pembangunan}

Dalam pembangunan peran serta seluruh lapisan masyarakat selaku aktor pembangunan dan pemerintah selaku pengayom dan pengarah sangat dibutuhkan. Antara pemerintah dan masyarakat harus seiring sejalan, saling melengkapi dalam gerak pembangunan untuk mencapai tujuan yang diharapkan. Pembangunan harus dilakukan mulai tingkat pusat sampai ditingkatan desa. Hanif (2011: 63) mendefinisikan pembangunan desa adalah proses perubahan yang terus menerus dan berkesinambungan yang diselenggarakan oleh masyarakat beserta pemerintah untuk meningkatkan kesejahteraan lahir dan batin, materi dan spiritual berdasarkan Pancasila yang berlangsung di desa. (Kepemimpinan et al., 2019)

Sjafrizal (2014:24) perencanaan pembangunan adalah cara atau teknik untuk mencapai tujuan pembangunan secara tepat, terarah dan efisien sesuai dengan kondisi daerah yang bersangkutan. Arthur W. Lewis mendefinisikan perencanaan pembangunan suatu kumpulan kebijaksanaan dan program pembangunan untuk merangsang masyarakat dan swasta untuk menggunakan sumber daya yang tersedia secara lebih produktif. Seorang profesional dalam dunia pelayanan publik seharusnya menguasai kebutuhan masyarakat, mengetahui cara memuaskan dan memenuhi kebutuhan masyarakat. (Jamal et al., 2020)

Salah satu kegiatan perencanaan pembangunan yang biasanya dilaksanakan adalah musyawarah perencanaan pembangunan yaitu forum-forum multi-pihak terbuka yang secara bersama mengidentifikasi dan menentukan prioritas kebijakan pembangunan masyarakat. (Tim Kerja Buku Panduan Penyelenggaraan Musrenbang, 2008 :3). (Mustanir \& Yasin, 2018b)

Pembangunan adalah kegiatan yang dilakukan untuk meningkatkan kesejahteraan warga. Sejahtera adalah kebalikan dari miskin. Merupakan tugas dari negara yang dijalankan oleh pemerintah -termasuk pemerintah desa- untuk mensejahterakan masyarakat dan mengatasi kemiskinan. Miskin adalah suatu kondisi di mana hak-hak dasar masyarakat tidak/belum terpenuhi. Hak-hak dasar merupakan kebutuhan dasar manusia tanpa kekecualian, tidak boleh dibedakan antara orang miskin atau kaya, laki-laki atau perempuan, agama apapun, suku/ras apapun, dan sebagainya. (Penyelenggaraan \& Pembangunan, n.d.)

Dalam Peraturan Menteri Dalam Negeri No.114 tahun 2014, tentang Pedoman Pembangunan Desa, yang dimaksud Perencanaan pembangunan desa adalah proses tahapan kegiatan yang diselenggarakan oleh pemerintah Desa dengan melibatkan Badan Permusyawaratan Desa (BPD) dan unsur masyarakat secara partisipatif untuk mengalokasikan dan memanfaatkan sumber daya yang ada dalam rangka mencapai tujuan pembangunan desa [11], [15] (Mustanir \& Razak, 2017)

Musyawarah rencana pembangunan menurut (Rondinelli, ADennis, dalam Widodo, (2011) (Mustanir 2017a) (Mustanir, n.d.) (Mustanir 2016a) (Akhmad, Mustanir, and Ramadhan 2018) (Juhannis 2016)) merupakan Perencanaan Pembangunan Bersama Masyarakat adalah panduan atau model pembangunan kelurahan yang menitikberatkan pada peran serta masyarakat dalam keseluruhan proses pembangunan. Pendekatan ini dilandasi oleh nilai-nilai dan semangat gotongroyong yang telah mengakar dalam budaya masyarakat Indonesia. (Mustanir, Muhammadiyah, Rappang, Andriani, et al., 2019)

Musyawarah Perencanaan Pembangunan (Musrenbang) desa adalah forum musyawarah tahunan para pemangku kepentingan (stakeholders) desa untuk m4wqenyepakati Rencana Kerja Pembangunan Desa (RKP Desa) tahun anggaran yang akan direncanakan. Musrenbang. (Pratama et al., 2018)

Keberhasilan pembangunan di suatu wilayah pemerintahan akan sangat diten- tukan oleh bagaimana kualitas perencanaan pembangunannya. Seperti dipahami bahwa perencanaan akan menunjukan arah yang jelas tentang apa yang menjadi kebutuhan warga dalam periode tertentu. Dengan perencanaan, semua kegiatan pembangunan dalam berbagai sektor memiliki target yang 
jelas dan terukur. Oleh karena itu perencanaan akan memudahkan para pelaku pem- bangunan dalam mencapai target- target yang telah ditentukan. Namun demikian, untuk memastikan bahwa pencapaian hasil agar sesuai dengan rencana maka diperlukan adanya pengendalaian atau pengawasan. (Yunas, 2017)

\section{Penutup}

\section{Kesimpulan}

Berdasarkan uraian diatas, dapat disimpulkan bahwa :

1). Peranan Aparatur Pemerintah Desa dalam Musyawarah Perencanaan Pembangunan Desa sangat penting karena berpengaruh dalam peningkatan kesejahteraan masyarakat.

2). Partisipasi Masyarakat dalam Pelaksanaan Musyawarah Perencanaan Pembangunan Desa dalam pelaksanaan setiap kegiatan harus melibatkan masyarakat, karena masyarakat ikut aktif dalam setiap kegiatan demi mencapai keberhasilan pembangunan Desa, dan

3). Faktor yang berpengaruh yaitu Faktor Internal kelompok masyarakat, jenis keterlibatan dalam kegiatan pembangunan desa sangat berpengaruh, baik dalam bentuk fisik maupun non fisik sedangkan Eksternal keterlibatan tokoh masyarakat yang memberikan motivasi dan pembinaan. 


\section{DAFTAR PUSTAKA}

Andi Uceng, A. A. (2019). Analisis Tingkat Partisipasi Masyarakat Terhadap Pembangunan Sumber Daya Manusia Di Desa Cemba Kecamatan Enrekang Kabupaten Enrekang. Moderat: Jurnal Ilmiah Ilmu, 5(2), 1-17.

Desa, M., Ulumiyah, I., Juli, A., Gani, A., \& Mindarti, L. I. (n.d.). PERAN PEMERINTAH DESA DALAM MEMBERDAYAKAN MASYARAKAT DESA (Studi pada Desa Sumberpasir Kecamatan Pakis Kabupaten Malang) Ita Ulumiyah, Abdul Juli Andi Gani, Lely Indah Mindarti. 1(5), 890-899.

Jamal, Y., Mustanir, A., \& Latif, A. (2020). Penerapan Prinsip Good Governance Terhadap Aparatur Desa Dalam Pelayanan Publik Di Desa Ciro-Ciroe Kecamatan Watang Pulu Kabupaten Sidenreng Rappang. PRAJA: Jurnal Ilmiah Pemerintahan, 8(3), 207-212. https://doi.org/10.51817/prj.v8i3.298

Kepemimpinan, A., Optimalisasi, T., Pada, M., \& Pembangunan, P. (2019). Analisis Kepemimpinan Terhadap Optimalisasi Masyarakat Pada Perencanaan Pembangunan Di Enrekang. 1-20. https://doi.org/10.20956/xxxxxx

Kunci, K., Pembangunan, P., \& Masalah, A. L. B. (2019). Peranan pemerintah desa dalam perencanaan pembangunan studi di desa pineleng dua kecamatan pineleng. April 2015.

Latif, A., Rusdi, M., Mustanir, A., \& Sutrisno, M. (2019). Partisipasi Masyarakat Dalam Pembangunan Infrastruktur Di Desa Timoreng Panua Kecamatan Panca Rijang Kabupaten Sidenreng Rappang Dosen Ilmu Pemerintahan Stisip Muhammadiyah Rappang Dosen Ilmu Administrasi Negara Stisip Muhammadiyah Rappang 5). Jurnal MODERAT, 5(1), 1-15. https://jurnal.unigal.ac.id/index.php/moderat/article/view/1898

Mustanir, A. (2019). Pemberdayaan Badan Usaha Milik Desa Melalui Kelompok Ekonomi Kewirausahaan Secara Partisipatif. March. https://doi.org/10.31219/osf.io/pwb2g

Mustanir, A., \& Darmiah, D. (2016). Implementasi Kebijakan Dana Desa Dan Partisipasi Masyarakat Dalam Pembangunan Di Desa Teteaji Kecamatan Tellu Limpoe Kabupaten Sidenreng Rappang. Jurnal Politik Profetik, 4(2), 225-238. http://journal.uinalauddin.ac.id/index.php/jpp/article/view/2749\%0Ahttp://journal.uinalauddin.ac.id/index.php/jpp/issue/view/457

Mustanir, A., Fitriani, S., Adri, K., Nurnawati, A. A., \& Goso, G. (2020). Sinergitas Peran Pemerintah Desa dan Partisipasi Masyarakat Terhadap Perencanaan Pembangunan di Kabupaten Sidenreng Rappang (The Synergy of Village Government's Role and Community Participation in the Process of Development Planning in Sidenreng Rappang D. Journal of Government Science (GovSci), 2020(2), 84-108.

Mustanir, A., Kamarudding, S., Akhwan, A., Madaling, \& Mutmainna. (2018). Peranan Aparatur Pemerintahan Desa dan Partisipasi Masyarakat Dalam Musyawarah Perencanaan Pembangunan di Desa Tonrongnge Kecamatan Baranti Kabupaten Sidenreng Rappang. Jurnal Ilmiah Clean Government, 2(Desember), 67-84. http://lonsuit.unismuhluwuk.ac.id/index.php/clean/article/view/213

Mustanir, A., Muhammadiyah, U., Rappang, S., Andriani, D., \& Sidoarjo, U. M. (2019). KARAKTERISTIK KEPEMIMPINAN LURAH TERHADAP PARTISIPASI MASYARAKAT DALAM MUSYAWARAH PERENCANAAN PEMBANGUNAN DI KELURAHAN DUAMPANUA KECAMATAN BARANTI KABUPATEN SIDENR $\ldots . . \quad J u l y$. https://doi.org/10.13140/RG.2.2.32893.51681

Mustanir, A., Muhammadiyah, U., Rappang, S., \& Irwan, A. (2019). Pengaruh Kepemimpinan Terhadap Partisipasi Masyarakat Pada Perencanaan Pembangunan. December. https://doi.org/10.31947/jakpp.v1i2.7977

Mustanir, A., \& Razak, M. R. R. (2017). Nilai Sosial Budaya Pada Partisipasi Masyarakat Etnik Towani Tolotang Dalam Musyawarah Rencana Pembangunan. Prosiding Konferensi Nasional Ke-6 Asosiasi Program Pascasarjana Perguruan Tinggi Muhammadiyah Aisyiyah (APPPTMA), September, 1-7. http://asosiasipascaptm.or.id/index.php/publikasi/prosidingkonferensi-nasional-appptma-ke-6 
Mustanir, A., \& Yasin, A. (2018a). Community Participation in Transect on Development Planning. Jurnal Ilmiah Ilmu Administrasi Publik, 8(2), 137. https://doi.org/10.26858/jiap.v8i2.7994

Mustanir, A., \& Yasin, A. (2018b). Transect Pada Perencanaan Pembangunan Partisipatif. 8(2), 21-31.

Penyelenggaraan, P., \& Pembangunan, M. P. (n.d.). Panduan penyelenggaraan musyawarah perencanaan pembangunan.

Pratama, M. R., Azikin, R., Ilmu, J., Negara, A., Makassar, U., Ilmu, J., Negara, A., Makassar, U., Ilmu, J., Negara, A., \& Makassar, U. (2018). UTARA. 4(April), 34-51.

Samad, Z., Mustanir, A., \& Pratama, M. Y. P. (2019). Partisipasi Masyarakat Dalam Musyawarah Rencana Pembangunan Untuk Mewujudkan Good Governance Kabupaten Enrekang. Moderat: Jurnal Ilmiah Ilmu Pemerintahan, 5(4), 379-395. https://jurnal.unigal.ac.id/index.php/moderat/article/viewFile/3014/2750

Wahyu, I. P. M., Noak, P. A., \& Erviantono, T. (2016). Peran Elit Desa dalam Partisipasi di Tingkat Lokal dalam Perumusan Musrembang di Desa Blahbatuh Kabupaten Gianyar. Politika Udayana, 1(1), 8.

Yunas, N. S. (2017). Efektivitas E - Musrenbang di Kota Surabaya dalam Sistem Perencanaan Pembangunan Berparadigma Masyarakat. 7(April), 19-27. 